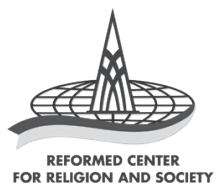

Societas Dei: Jurnal Agama dan Masyarakat

Vol. 7, No. 2 (October 2020): 149-172

http://societasdei.rcrs.org/index.php/SD/issue/archive

p-ISSN: 2407-0556; e-ISSN: 2599-3267

DOI: $10.33550 /$ sd.v7i2.165

Received: 13 June 2020

Revised: 29 July 2020

Accepted: 1 September 2020

\title{
AMICA CENSURA: \\ PEMIKIRAN NICHOLAS CUSANUS \\ TENTANG AGAMA-AGAMA, \\ SEBUAH REFLEKSI DAN APLIKASI TERHADAP KONFLIK ANTARAGAMA DI INDONESIA
}

\section{AMICA CENSURA: \\ THE THOUGHTS OF NICHOLAS CUSANUS ABOUT RELIGIONS, A REFLECTION AND APPLICATION TOWARDS INTERRELIGIOUS CONFLICT IN INDONESIA}

Jessica Novia Layantara

Universitas Pelita Harapan, Tangerang

jessica.layantara@uph.edu 


\begin{abstract}
:
Interreligious conflicts often occur in Indonesia, a country with various beliefs and religions. In this article, I approach these conflicts using the thoughts of Nicholas Cusanus, a medieval Catholic thinker who also faced interreligious conflict of his time, the Fall of Constantinople to Ottoman Turks. I analyze Cusanus' thought about religions in his works, De Pace Fidei and Cribratio Alkorani, which prove that Cusanus position on other religions is in the midst of exclusivism and pluralism. Afterwards, I will suggest reflection and application based on: 1. Interpretation of the work of Cusanus De Pace Fidei and Cribratio Alkorani, 2. Contextualizing the interpretation with interreligious conflict in Indonesia, appreciatively and critically. There are three points of reflection and application in this article: 1. A non-violent approach to other religions, 2. Sensitivity to political interests in interreligious conflict, 3. Initiates friendly and open dialogue between religions, and 4. Increase active tolerance that breaks down the dividing walls.
\end{abstract}

Keywords: Nicholas Cusanus; pluralism; exclusivism; inclusivism; interreligious conflict.

\begin{abstract}
Abstrak:
Konflik antaragama merupakan konflik yang sering terjadi di Indonesia, di mana masyarakatnya menganut beragam kepercayaan. Dalam artikel ini, konflik antaragama didekati menggunakan pemikiran Nicholas Cusanus, seorang pemikir Katolik pada Abad Pertengahan, yang juga menghadapi konflik antaragama sehubungan dengan jatuhnya Konstantinopel ke tangan Ottoman Turki. Artikel ini menganalisis pemikiran Cusanus mengenai agama-agama lain dalam karyanya: De Pace Fidei dan Cribratio Alkorani. Dari analisis tersebut, dapat ditarik sebuah tesis bahwa posisi Cusanus berada di tengah-tengah eksklusivisme dan pluralisme, yang pada akhirnya melahirkan refleksi dan aplikasi, bagi konflik antaragama di Indonesia. Refleksi dan aplikasi ini dibentuk berdasarkan: 1 . Interpretasi terhadap karya Cusanus De Pace Fidei dan Cribratio Alkorani, 2. Kontekstualisasi interpretasi secara apresiatif dan kritis terhadap konflik antaragama di Indonesia. Tiga poin refleksi dan aplikasi yang diambil dari pemikiran Cusanus menghadapi konflik antaragama antara lain: 1. Pendekatan antikekerasan, 2. Kepekaan terhadap kepentingan politik, 3. Inisiasi dialog antaragama yang bersahabat dan terbuka, dan 4. Peningkatan toleransi antaragama secara aktif yang berusaha meruntuhkan tembok-tembok pemisah.
\end{abstract}

Kata-kata kunci: Nicholas Cusanus; pluralisme; eksklusivisme; inklusivisme; konflik antaragama. 


\section{Pendahuluan}

Indonesia merupakan negara yang penuh keberagaman. Salah satu keberagaman yang patut disoroti adalah dalam hal menganut kepercayaan atau agama. Negara Indonesia menjamin kebebasan masing-masing warga negara untuk memilih dan menjalankan agamanya masing-masing. Ada enam agama yang telah diakui oleh negara, yaitu Islam, Kristen, Katolik, Hindu, Buddha, dan Kong $\mathrm{Hu} \mathrm{Cu}$.

Meskipun pemerintah menjamin kebebasan beragama setiap warga negara, konflik antaragama masih tetap terjadi di Indonesia. Sebut saja konflik antaragama yang terjadi di Poso antara umat Islam dan Kristen tahun 1998-2001, di Ambon antara umat Islam dan Kristen tahun 1999, di Tolikara antara umat Islam dan Kristen tahun 2015, dan di Singkil-Aceh antara umat Islam dan Kristen tahun 2015, di Tanjungbalai antara umat Islam dan Buddha tahun 2016, di Papua antara umat Islam dan Kristen tahun 2018. ${ }^{1}$ Konflik-konflik ini pada umumnya berakar pada masalah kepercayaan, di mana pemeluk agama tertentu merasa agama lain mendominasi daerahnya (seperti konflik di Poso), atau karena umat agama tertentu dirasa mengancam kepercayaan agama lain (seperti konflik di Tanjungbalai, Tolikara, dan Aceh). Konflik-konflik tersebut dapat digolongkan sebagai konflik besar dan rumit karena melibatkan massa hingga menimbulkan korban jiwa. Selain konflik-konflik besar tersebut, masih terjadi konflik-konflik kecil lain yang melibatkan agama, seperti pencemaran agama², penghinaan simbol-simbol maupun doktrin keagamaan ${ }^{3}$, pendirian rumah ibadat ${ }^{4}$, dan lain-lain.

Rawannya konflik antarumat beragama di Indonesia mengingatkan akan konflik yang terjadi di abad ke-14 antara umat Islam, yang diwakili Ottoman Turki, dengan umat Katolik/Kristen di Eropa sehingga mengakibatkan jatuhnya Konstantinopel. Konflik ini bersifat politis, namun melibatkan dua agama besar yaitu Islam dan Katolik/Kristen, di mana kejatuhan Konstantinopel dianggap sebagai ancaman bagi keberadaan agama Kristen di Eropa. Namun di tengah konflik umat Islam dan Kristen ini, seorang kardinal Katolik, Nicholas Cusanus, memilih untuk membangkitkan

\footnotetext{
Puput Purwanti, "Tujuh Contoh Konflik Antar Agama Yang Pernah Terjadi Di Indonesia," Hukumnas (28 Desember 2017) accessed May 15, 2020, https://hukamnas.com/contoh-konflik-antar-agama; Samala Mahadi, “Lima Konflik Agama Terbesar Di Indonesia,” Berita Properti 99.co, (24 Desember 2019), accessed May 15, 2020, https://www.99.co/blog/indonesia/konflik-agama-indonesia/.

2 Tempo.co, "Penistaan Agama," accessed May 15, 2020, https://www.tempo.co/tag/penistaan-agama.

“Rizieq Shihab Dilaporkan ke Polisi, Dituduh Lecehkan Umat Kristen," BBC News, (26 Desember 2016), diakses pada 14 April 2020, https://www.bbc.com/indonesia/indonesia-38435195.

“Sewindu, Umat GKI Yasmin-HKBP Filadelfia Natal di Luar Istana," CNN Indonesia,(25 Desember 2019), diakses pada 15 Mei 2020, https://www.cnnindonesia.com/nasional/20191225185015-20-459879/ sewindu-umat-gki-yasmin-hkbp-filadelfia-natal-di-luar-istana.
} 
semangat perdamaian di tengah-tengah kebencian yang terjadi. Tidak seperti rekan-rekan sesama Katolik yang memilih untuk mendukung semangat memerangi Islam dengan perang (contohnya guru Cusanus sendiri, Ramon Lull), Cusanus memilih untuk mengumandangkan semangat perdamaian. Dalam bukunya, Miroslav Volf menyebut Cusanus sebagai seorang model yang memberikan pendekatan dengan cara yang positif terhadap Islam. Cusanus merespons kejatuhan Konstantinopel dengan menyerukan persatuan daripada mengangkat senjata. ${ }^{5}$

"Una religio in rituum varietate!" 6 seru Cusanus dalam bukunya: De Pace Fidei. Di dalam karya inilah, Cusanus mendasarkan pandangannya tentang relasi antaragama. Karya Cusanus yang selanjutnya, Cribatio Alkorani, juga merupakan penafsiran yang bersahabat (pia interpretatio) terhadap Islam dan Qur'an. Meski sangat kritis dalam memandang Islam dan Qur'an, tulisan Cusanus tetap memiliki semangat, yang menurut F. Dallmayr, adalah $a$ spirit of goodwill, friendliness, and reconciliation. ${ }^{7}$ Sikap Cusanus yang inklusif, bersahabat, dan nirkekerasan terhadap agama-agama lain membuat penulis tertarik untuk membahas pemikirannya. Pemikiran Cusanus dapat menjadi sebuah refleksi teologis bagi toleransi umat beragama di Indonesia, secara khusus mendorong toleransi dari pihak orang Kristen. Konteks yang dihadapi Cusanus, meskipun tidak sama persis, mengandung unsur yang sama dengan apa yang terjadi di Indonesia, yaitu konflik antaragama.

Dalam penelitian yang berjudul "Cusanus, Islam, and Religious Tolerance," Morimichi Watanabe mengatakan bahwa saat ini ada lebih dari 1,6 miliar orang yang menganut agama Islam di seluruh dunia, dan ada 44 negara yang memiliki mayoritas berpenduduk Muslim. Watanabe menyoroti bahwa Indonesia merupakan salah satu dari 44 negara tersebut. Di bagian terakhir artikelnya, Watanabe mengatakan bahwa pemikiran Cusanus mengenai toleransi adalah pemikiran yang paling baik untuk mendekati masalah toleransi di negara-negara mayoritas Muslim. ${ }^{8}$ Artikel ini mencoba untuk melanjutkan perhatian Watanabe pada krisis toleransi di negara-negara mayoritas Muslim walaupun Indonesia belum pernah dibahas oleh Watanabe secara khusus. Oleh sebab itu, penulis hendak memberikan ulasan terhadap pemikiran Cusanus mengenai agama-agama dalam karya-karyanya, serta mengaitkannya secara reflektif sekaligus aplikatif

\footnotetext{
Miroslav Volf, Allah: A Christian Response (New York: Harper Collins, 2011), 40.

Kalimat ini berarti: "Satu agama beragam ritual."

Fred Dallmayr, "Desire and the Desirable: Nicholas de Cusanus's Interfaith Imagination," Religion and the Arts 12, no. 1-3 (2008): 426.

Morimichi Watanabe, "Cusanus, Islam, and Religious Tolerance," in Nicholas of Cusa and Islam: Polemic and Dialogue in the Late Middle Ages, ed. Christopher M. Bellitto, Thomas M. Izbicki, and Gerald Christianson (New York: Paulist, 2004), 19.
} 
dengan konflik-konflik antaragama yang terjadi di Indonesia, khususnya pendekatan Cusanus yang dialogis dan antikekerasan.

Artikel ini akan dibagi menjadi tiga bagian, yaitu pendahuluan, isi dan kesimpulan. Bagian pendahuluan akan membahas latar belakang penulisan artikel ini. Di dalam bagian isi, penulis akan memaparkan terlebih dahulu latar belakang konflik-konflik antaragama Islam dan Kristen dan zaman di mana Cusanus hidup. Kemudian, penulis akan membahas pandangan Cusanus mengenai toleransi antaragama dalam karya-karyanya, khususnya di dalam De Pace Fidei dan Cribatio Alkorani. Dua karya tersebut secara langsung menyentuh konflik Islam-Kristen. Di subbagian isi, penulis juga akan menganalisis model pendekatan Cusanus terhadap agama-agama. Di bagian terakhir, penulis akan mengaitkan pemikiran Cusanus mengenai agama-agama dengan konflik antaragama di Indonesia.

\section{Metode Penelitian}

Metode yang digunakan dalam artikel ini adalah penelitian kepustakaan (library research). Metode penelitian kepustakaan akan dilakukan melalui pengumpulan data-data kepustakaan seperti buku-buku, jurnaljurnal, dan sumber-sumber daring. Metode kepustakaan meliputi proses elaborasi pandangan Nicholas Cusanus mengenai agama-agama, khususnya agama Islam dalam dua karyanya, yaitu De Pace Fidei dan Cribratio Alkorani. Proses penelitian akan dilanjutkan dengan mengidentifikasi dan menganalisis pandangan Cusanus dalam kerangka tripolar teologi agama-agama. Data-data yang telah dikumpulkan tersebut kemudian dicari relevansinya dengan konflik antaragama di Indonesia, dan bagaimana pandangan tersebut dapat direfleksikan serta diaplikasikan dalam menghadapi konflik antaragama di Indonesia.

\section{Diskusi}

Nicholas de Cusanus dan Dua Konflik Dilematis

Nicholas de Cusanus (1401-1464) hidup di zaman yang penuh konflik. Setidaknya, ada dua konflik besar yang menunjukkan respons Cusanus terhadap konflik agama yaitu konflik antara papalisme dan konsiliarisme, dan konflik antara Ottoman Turki dan papal Eropa. Konflik papalisme ${ }^{9}$ dan konsiliarisme ${ }^{10}$ tepatnya dimulai tahun 1431, di mana Konsili Basel

\footnotetext{
Papalisme (Papalism) adalah sistem yang terlalu membesarkan kuasa Paus dan mengabaikan peran uskup lain. Lih. Gerald O' Collins and Edward G Farrugia, Kamus Teologi (Yogyakarta: Kanisius, 1996), 229.

10 Konsiliarisme (Conciliarism) adalah teori yang berkembang pada masa skisma besar, teori ini mengatakan bahwa kuasa tertinggi gereja ada pada konsili ekumenis, bukan Paus. Lih. Ibid., 152.
} 
terbentuk untuk menuntut perpindahan kekuasaan gereja dari Paus kepada Konsili. Merespons konflik ini, Cusanus menulis De Concordantia Catholica, yang menurut Anton G. Weiler, De Concordantia Catholica bertujuan untuk merestorasi perdamaian dalam gereja, dan mengembalikan harmonisasi ilahi dalam gereja, yang pada saat itu dikuasai penuh oleh kepausan. ${ }^{11}$ Dari konflik pertama ini, yaitu konflik internal gereja Katolik, dapat dilihat bahwa Cusanus adalah sosok yang selalu mendambakan perdamaian antara dua pihak yang berkonflik.

Konflik kedua adalah konflik antara Ottoman Turki dengan papal Eropa. Jika konflik pertama yang mempengaruhi Cusanus adalah konflik internal agama Katolik, konflik kedua ini merupakan konflik antara agama Katolik dengan agama Islam. Pada saat konflik kedua ini terjadi, situasi hidup Cusanus dalam saat yang bersamaan sedang kurang baik. Perseteruan Cusanus dengan Duke Sisigmund of the Tyrol, yang akhirnya berakhir pada penyekapan Cusanus di Istana Bruneck, membuat masa-masa hidup Cusanus pada saat itu sangat kelam. ${ }^{12}$ Masa kelam ini ditambah dengan jatuhnya Konstantinopel oleh Ottoman Turki (1453). Jatuhnya Konstantinopel ini merupakan sebuah pukulan besar bagi umat Kristen, yang menganggap Konstantinopel sebagai pusat perkembangan agama Kristen sejak Perang Salib pertama (1096). Sebelum kejatuhan Konstantinopel, agama Islam sendiri pada masa itu bukan ancaman bagi keberadaan kekristenan di Eropa. Biechler berkata, "As religious ideology the claims of Islam had been studied, analyzed, discussed, and thoroughly refuted down through the Middle Ages. No, as religion, it would appear, Islam was no longer a real threat. It was now the Ottoman Empire that posed the problem and that problem was quite simply military and political."13

Namun kuatnya serangan Ottoman Turki yang mengakibatkan jatuhnya Konstantinopel menimbulkan kekhawatiran bagi umat beragama Katolik/Kristen di Eropa, bahwa agama Islam juga akan berkuasa dan mendominasi Eropa. Biechler mengatakan, "The Ottomans were a threat because the West perceived them not merely as potentially disruptive of current economic or political arrangements but as radically hostile to European Christendom, i.e., as striking at the very roots of Western culture."14 Kekhawatiran ini memi-

\footnotetext{
11 Anton G. Weiler, "Nicholas of Cusa on Harmony, Concordance, Consensus and Acceptance as Categories of Reform in the Church, in De Concordantia Catholica," in Conflict and Reconciliation: Perspectives on Nicholas of Cusa, ed. Inigo Bocken (Leiden: Brill, 2004), 77.

12 Erich Meuthen, Nicholas of Cusa: A Sketch for a Biography (Washington D.C.: The Catholic University of America Press, 2010), 112-114.

13 James E. Biechler, “Nicholas of Cusanus and Muhammad: A Fifteenth-Century Encounter," The Downside Review 101, No. 342 (1983): 3.

14 Ibid.
} 
liki kemiripan dengan motif yang melandasi konflik-konflik agama pada umumnya, termasuk di Indonesia yakni ketakutan bahwa agamanya akan didominasi oleh agama dan kepercayaan lain.

Pada umumnya kejatuhan Konstantinopel direspons dengan kemarahan orang-orang Kristen, termasuk Paus Nicholas V dan Paus Pius II. Paus Nicholas $\mathrm{V}$ menginginkan adanya perang suci melawan Ottoman Turki dan semua pemimpin Kristen diminta menyetujui hal tersebut. Pengganti Paus Nicholas V, Paus Pius II, juga menginisiasi perang lagi pada tahun 1461. Paus Pius II, yang juga merupakan sahabat dari Cusanus, secara khusus meminta Cusanus untuk menulis kritik terhadap Al-Qur'an, yang diselesaikan Cusanus dalam Cribratio Alkorani. Namun tidak seperti Paus dan orang-orang Kristen semasanya yang bereaksi dengan penuh kemarahan bahkan meminta perang, Cusanus dan sahabatnya, John of Segovia, mengusulkan perdamaian. Cusanus menerbitkan karyanya, De Pace Fidei (1453), di mana Cusanus mengusung semangat perdamaian antaragama, yang berkontradiksi dengan reaksi orang Kristen Eropa kebanyakan. Sedangkan John of Segovia, mempelajari terjemahan Qur' an dengan teliti untuk membuat diskusi antaragama. Setahun setelah itu, John of Segovia mengirimkan surat pada Cusanus untuk mengajaknya mengadakan pertemuan bersama dengan teolog-teolog Kristen dan otoritas sipil demi menyerukan perdamaian dengan umat Muslim. Menurut Segovia, perdamaian melalui dialog satu sama lain adalah satu-satunya jalan menghadapi konflik Islam-Kristen pada masa itu. ${ }^{15}$

Perjuangan Cusanus dan Segovia tidak mudah, mengingat mereka harus berhadapan dengan Paus dan banyak pemimpin Kristen yang lebih memilih kekerasan dibandingkan perdamaian untuk menghadapi umat Islam. Pada tahun 1461, Paus Pius II memerintahkan Cusanus untuk pergi ke Ancona mendukung perang. Ketika Cusanus sedang dalam perjalanan menuju Ancona, ia jatuh sakit di Todi pada tahun 1461 dan meninggal pada tahun 1464, sehingga tidak pernah diketahui dengan jelas apa sikap Cusanus jika seandainya dia berhasil menemui Paus Pius II saat itu. Sejarah mencatat bahwa perang yang diusulkan Paus Pius II maupun diskusi antaragama yang diinisiasi Cusanus dan Segovia sama-sama tidak terjadi.

\section{Pemikiran Cusanus mengenai Agama-agama}

Sebelum kejatuhan Konstantinopel, Cusanus telah menunjukkan minatnya secara jelas pada studi agama-agama. Menurut James E. Biechler,

15 James E. Biechler, “Interreligious Dialogue," in Introducing Nicholas of Cusa: A Guide to a Renaissance Man, ed. Christopher M. Bellitto, Thomas M. Izbicki, and Gerald Christianson (New York: Paulist Press, 2004), 280. 
kemungkinan Ramon Lull dan karya-karyanya adalah yang pertama kali membimbing Cusanus pada kemungkinan dibentuknya agama universal, di mana agama ini dapat memeluk perbedaan yang ada dalam agama-agama seperti Kristen, Islam, Hindu, Yahudi, dan lain-lain. ${ }^{16}$ Demikian juga pengaruh sahabatnya, John of Segovia, yang berkecimpung langsung dalam dialog-dialog dengan penganut Islam berkebangsaan Spanyol, ikut berperan dalam ketertarikan Cusanus pada agama-agama lain, khususnya Islam.

Dalam kunjungan Cusanus ke Basel, ia mendapatkan terjemahan Al-Qur'an dalam bahasa Latin, yang diselesaikan oleh Robert Ketton, serta koleksi tulisan-tulisan lain mengenai Islam, yaitu kumpulan naskah Toledan. Sampai saat ini naskah dan koleksi tersebut masih disimpan di Perpustakaan Rumah Sakit Nicholas di Cusanus. Namun dapat dikatakan bahwa kejatuhan Konstantinopel membuat Cusanus benar-benar harus mendalami ketertarikannya akan agama-agama ini. Untuk respons pertamanya atas kejatuhan Konstantinopel, ia menulis De Pace Fidei. Delapan tahun kemudian, ia menulis Cribratio Alkorani sebagai dukungan terhadap Paus Pius II yang ingin mengkritik ajaran Islam. Pemikiran Cusanus mengenai agama-agama dalam bagian ini akan ditelusuri terutama melalui dua karya Cusanus: De Pace Fidei (1453) dan Cribratio Alkorani (1461).

\section{De Pace Fidei}

De Pace Fidei adalah karya utama yang sangat penting dalam pemikiran Cusanus mengenai agama-agama. Cusanus menyelesaikan De Pace Fidei beberapa bulan setelah kabar kejatuhan Konstantinopel oleh Ottoman Turki. Kejatuhan Konstantinopel, yang merupakan pusat dari berkembangnya kekristenan pada abad tersebut, menimbulkan kekhawatiran bahwa selanjutnya Turki benar-benar akan menguasai wilayah Kristen di Eropa. Dalam kekhawatiran itu, Cusanus memilih untuk menulis De Pace Fidei, yang merupakan ajakan untuk memandang semua agama sebagai agama yang satu, termasuk Islam.

Inklusivisme dalam De Pace Fidei sangat kental. Cusanus berpendapat bahwa Tuhan yang sama mengirimkan berbagai nabi dalam setiap agama untuk mewahyukan diri-Nya. Tujuan semua agama, dengan demikian, adalah sama, yaitu untuk mencari Sang Baik Absolut tersebut (Tuhan). Namun menurut Cusanus, Allah adalah misteri, sehingga tidak ada satu agama pun yang dapat mengklaim bahwa agamanya mengetahui rahasia dan misteri Allah sepenuhnya, "You, then, who are the giver of life and of existence, are the one who is seen to be sought in different ways in different rites,

$16 \quad$ Ibid., 273. 
and You are named in different names; for as You are [in Yourself] You remain unknown and ineffable to all."17 Tuhan hanya mewahyukan diri-Nya seturut kehendak-Nya, pada masing-masing agama tentang diri-Nya. Oleh sebab itu, semua agama adalah satu dan sama karena memiliki Tuhan yang sama.

Walaupun semua agama adalah satu, setiap agama memiliki ritual yang berbeda (una religio in rituum varietate). Perbedaan ritual tidak harus dihilangkan karena justru menyebabkan seseorang makin menyembah Tuhan dengan lebih sungguh-sungguh. ${ }^{18}$ Setiap pelaku ritual akan berlomba-lomba untuk mempersiapkan upacara dan ritual yang terbaik untuk Tuhan yang sama tersebut. Bukan berarti Cusanus tidak menekankan keistimewaan Kristen di antara agama-agama lain. Dalam buku ini, Cusanus membuat sebuah diskusi imajiner dengan orang-orang bijak dari berbagai suku bangsa seperti Yunani, Italia, Arab, Indian, Chaldean, Yahudi, Scythian, Frenchman, Persian, Syrian, Spaniard, Turki, Jerman, Tartar, Armenian, Bohemian, Inggris. Ketujuh belas orang ini dikumpulkan di surga untuk mendiskusikan soal agama mereka dengan Sang Firman (Word), Petrus, dan Paulus. ${ }^{19}$ Dalam setiap negara ini sebenarnya tercermin pula kepercayaan mereka yang berbeda-beda. Contoh, orang Arab dalam buku ini mencerminkan kepercayaan Islam, yang monoteistis dan menentang Trinitas serta dua natur Kristus.

Ide utama dari buku ini adalah Cusanus mencoba memberitahukan pada pembaca bahwa Allah Trinitas yang dipercayai oleh orang Kristen seharusnya tidak ditolak oleh agama-agama lain. Sang Firman yang digambarkan Cusanus sebagai perwakilan Kristen mengemukakan prinsip kesatuan (unitas), kesederajatan (aequalitas), dan relasi (connexio) sebagai prinsip yang tidak mungkin ditolak oleh semua agama, dan tiga prinsip itu adalah Allah Trinitas di dalam kekristenan. Cusanus juga menyoroti secara khusus doktrin Islam yang mengatakan Allah memiliki roh, firman, dan nafas. Menurut Cusanus, ketiga prinsip ini bukan sesuatu yang dimiliki Allah, melainkan ketiganya adalah wujud pribadi Allah. Cusanus menulis, "Hence, the Arab does not deny that God is Mind, and that the Word, or Wisdom, is begotten from Mind, and that from Mind and the Word there proceeds the Spirit, or Love." ${ }^{20}$ Oleh sebab itu, menurut Cusanus, jika diselidiki maka Islam sama sekali tidak menolak doktrin Trinitas.

17 Nicholas of Cusa, Nicholas of Cusa's De Pace Fidei and Cribratio Alkorani: Translation and Analysis, ed. Jasper Hopkins (Minneapolis: The Arthur J. Banning Press, 1994), chap. I.5.

$18 \quad$ Ibid., chap. I.6.

19 Ibid., chaps. I \& II.

$20 \quad$ Ibid., chap. IX.6. 
Selanjutnya, Cusanus berusaha meyakinkan bahwa semua agama yang ada di dunia ini pada akhirnya akan menuntun pada konsep Allah Trinitas, yang terwahyukan dalam agama Kristen. Dalam penjelasannya pada orang Arab dan Yahudi, Kristus dalam De Pace Fidei mengatakan, "In the manner in which the truth of the Trinity is explained above, of necessity it will be embraced by all." ${ }^{21}$ Bahkan, Trinitas adalah puncak dari pewahyuan Sang Kebijaksanaan Absolut (Tuhan). Respons orang Scynthian dalam De Pace Fidei menyuratkan hal ini, "In this way, we see clearly that all the wise have attained unto some [conception of] trinity-in-oneness. And so, they will rejoice and give praise when they hear the [same] explanation [of the Trinity] that we have heard."22 Bagi Cusanus, Trinitas adalah dasar bersama (common ground) antara kekristenan dengan agama lain. Terkhusus agama Islam, Cusanus tidak pernah sekalipun dalam buku ini menyebut bahwa Islam adalah agama yang salah atau anti-Kristen. Euler berkata,

It becomes clear that Cusanus does not consider Islam to be hopelessly corrupted, anti-Christian, and demoniacal, but instead finds that it contains a true and sane core that needs to be carefully exposed first... Therefore, throughout his work there is not a single sentence, not a single thought condemning Islam as a fundamentally anti-Christian religious system. ${ }^{23}$

Keseluruhan buku De Pace Fidei adalah pencarian harmoni berbagai agama dalam dialog yang bersahabat. Morimichi Watanabe mengatakan, "The general tone of De Pace Fidei is very peaceful and harmonious. It is clear that Cusanus took an attitude that sought harmony and tried to find a basic, common theme among the various world religions." ${ }^{24}$ Dalam buku ini Cusanus mencoba menawarkan sebuah pendekatan lain sesudah kejatuhan Konstantinopel selain kebencian dan perang, yaitu pendekatan dialogis dan membangun pengertian satu sama lain, khususnya menemukan dasar bersama pada tataran epistemologis, yaitu melalui Trinitas.

\section{Cribratio Alkorani}

Cribratio Alkorani merupakan karya penting Cusanus di tahun-tahun terakhir hidupnya. ${ }^{25}$ Dalam buku ini, Cusanus mendekati Islam dengan cara yang sangat berbeda dengan De Pace Fidei. Menurut Morimichi Watanabe, ada empat faktor yang menyebabkan perubahan sikap Cusanus ini. ${ }^{26}$

21 Ibid., chap. IX.26.

22 Ibid., chap. X.27.

23 Walter Andreas Euler, "A Critical Survey of Cusanus's Writings on Islam," in Nicholas of Cusa and Islam: Polemic and Dialogue in the Late Middle Ages, ed. Ian Christopher Levy, Rita George-Tvrtković, and Donald Duclow (Leiden: Brill, 2014), 22-23.

24 Watanabe, "Cusanus, Islam, and Religious Tolerance," 10.

25 Euler, "A Critical Survey of Cusanus's Writings on Islam," 27.

26 Watanabe, "Cusanus, Islam, and Religious Tolerance," 14. 
Pertama, dapat dikatakan bahwa pada masa itu studi Cusanus mengenai Islam telah mencapai tahap yang lebih dalam sehingga Cusanus dapat mengeksposisi Qur'an dengan lebih percaya diri. Dapat dikatakan dalam poin ini, perubahan sikap Cusanus didorong oleh makin dalamnya pengertian teologis mengenai agama Islam. Kedua, harus dipertimbangkan bahwa pada masa itu Cusanus telah mendapatkan posisi di dalam gereja Katolik. Pada tahun 1459, Cusanus bahkan menjadi representasi dari Paus Pius II. Oleh sebab itu dapat dimengerti mengapa Cusanus bersikap lebih kritis pada Islam, yang pada saat itu merupakan musuh besar dari Katolik. Di sini tidak dapat dipastikan apakah posisi politik Cusanus berubah sama seperti Paus, yaitu mendukung perang. Sesuatu yang dapat dipastikan adalah dalam posisi Cusanus saat itu, sangat sulit untuk langsung mengungkapkan ketidaksetujuan dengan Paus dalam posisi politiknya.

Ketiga, persahabatan Cusanus dengan Paus Pius II, yang merupakan pendukung utama diadakannya perang, kemungkinan besar mempengaruhi pandangan Cusanus. Permintaan Paus Pius II untuk Cusanus mengkritik Islam pun dipenuhi dalam buku Cribratio Alkorani. Cusanus menuliskan dengan jelas di halaman pertama buku tersebut bahwa buku itu dipersembahkan untuk Paus Pius II, "O, most holy Pope, accept this book composed with zealous faith by your humble servant." ${ }^{27}$ Keempat, kemungkinan terjemahan Latin Al-Qur'an yang digunakan Cusanus, yaitu yang diselesaikan oleh Robert Ketton, mengandung beberapa kesalahan sehingga Cusanus juga salah memahami bagian-bagian dalam Al-Qur'an, dan menyebabkan kritik yang lebih tajam daripada yang seharusnya. ${ }^{28}$

Dalam Cribratio Alkorani, Cusanus mengkritik isi Qur'an. Cusanus mengkritik kesejarahan Qur'an, di mana ia menemukan beberapa kesalahan historis dalam Qur'an, contohnya Qur'an menyebutkan Maria, ibu Yesus, sebagai anak Amram, saudara Musa dan Harun. Padahal Maria, ibu Yesus, hidup di zaman yang berbeda dengan Musa dan Harun. ${ }^{29}$ Demikian juga Qur'an pasal 75 mengatakan bahwa Maria mengonfirmasi kebenaran Qur'an, padahal Qur'an baru muncul 600 tahun setelah kematian Maria. ${ }^{30}$ Cusanus juga mengkritik bahwa Qur'an tidak konsisten, di satu sisi Qur'an menjunjung tinggi Injil sebagai kebenaran, namun di sisi lain banyak isi Qur'an yang bertentangan dengan Injil. ${ }^{31}$

27 Nicholas of Cusa, Nicholas of Cusa's De Pace Fidei and Cribratio Alkorani: Translation and Analysis, chap. Prologue, 1.

28 Watanabe, "Cusanus, Islam, and Religious Tolerance," 14.

29 Nicholas of Cusa, Nicholas of Cusa's De Pace Fidei and Cribratio Alkorani: Translation and Analysis, bk. I.4.32.

$30 \quad$ Ibid., bk. I.4.33.

$31 \quad$ Ibid., bk. I.4.34. 
Cusanus juga menyelidiki sosok Nabi Muhammad di dalam Qur'an. Menurut Biechler, Cusanus tertarik untuk menyelidiki hidup dan ajaran Nabi Muhammad, sehingga ia memberi banyak detail tentang Nabi Muhammad. ${ }^{32}$ Namun demikian, Cusanus menekankan keunggulan pada kehidupan dan ajaran Kristus di atas Nabi Muhammad. Jika ada ajaran Nabi Muhammad yang bertentangan dengan ajaran Kristus, maka berarti Muhammadlah yang salah. Cusanus menjelaskan,

If Muhammad in any respect disagrees with Christ, then it follows either that he does so out of ignorance, because he did not know Christ and did not understand Him, or that there is perverse intent, because he did not intend to lead men to that goal-of-rest to which Christ showed the way but rather sought his own glory under the guise of that goal. ${ }^{33}$

Melalui kritiknya ini sebenarnya Cusanus ingin menekankan keilahian Kristus, yang tentunya jika dibandingkan Nabi Muhammad, Kristus lebih unggul. Mengenai kesalahan dalam ajaran Muhammad, Cusanus berpendapat bahwa Nabi Muhammad telah ditipu oleh ajaran Nestorian dan Yahudi, sehingga ia menerima pengertian yang salah tentang Yesus. Walapun seringkali mendiskusikan Muhammad dengan keras, tapi Cusanus juga tidak menyangkali bahwa Muhammad memiliki inspirasi ilahi. Campi mengatakan, "Yet, he was also quite harsh when he discussed Muhammad and one can find many of the previous Christian indictments against him. Even then, he still allowed for the possibility that Muhammad had some valid religious inspiration as well." 34

Mengenai Al-Qur'an, Cusanus meyakini Qur'an pasti dikumpulkan dari pecahan-pecahan Injil, karena mengandung banyak kesamaan dengan Injil dan juga mengakui kebenaran Injil. Seandainya ada hal-hal yang bertentangan dengan Injil, maka ajaran Qur'an itu harus ditolak. ${ }^{35}$ Sikap Cusanus ini menekankan kembali keyakinannya pada agama-agama dalam De Pace Fidei: agama hanya ada satu, ritual ada banyak, oleh sebab itu semua agama sesungguhnya adalah satu, dan jika ada perbedaan, sangat mungkin ada kesalahan di dalam pemahaman salah satu agama.

Dalam menafsirkan Al-Qur'an, Cusanus menggunakan metode Pia Interpretatio atau penafsiran yang bersahabat (loving interpretation). Frasa ini

32 Biechler, "Interreligious Dialogue," 286.

33 Nicholas of Cusa, Nicholas of Cusa's De Pace Fidei and Cribratio Alkorani: Translation and Analysis, bk. Prologue, 9.

34 Emidio Campi, "Early Reformed Attitudes towards Islam," Theological Review of the Near East School of Theology 31, no. 1985 (2010): 136.

35 Nicholas of Cusa, Nicholas of Cusa's De Pace Fidei and Cribratio Alkorani: Translation and Analysis, bk. I.4.34. 
muncul empat kali dalam buku ini. ${ }^{36}$ Dalam penafsirannya, Cusanus menegaskan bahwa ia akan berusaha mencari dasar bersama (common ground) antara ajaran Kristen dan Islam. Cusanus beberapa kali menyoroti kesamaan ajaran Qur'an dengan Alkitab, contohnya keduanya mengajarkan bahwa Allah adalah Pencipta, bahwa Tuhan mahakuasa, pengampun, tidak terbatas, dan pada akhirnya akan menghakimi semua orang. ${ }^{37}$

Metode Pia Interpretatio juga membuat Cusanus mengabaikan bagian-bagian Al-Qur'an yang problematis, seperti halnya gaya hidup Muhammad, pernikahannya, atau polemik upah bidadari di Sorga. ${ }^{38}$ Sebaliknya, dia berfokus pada ajaran-ajaran yang dapat disetujui dalam kekristenan. Watanabe mengatakan, "Cusanus recommended that, in the Qur'an, one should pay attention only to the teachings that are more agreeable to the Christian gospel and harmonious with the writings of the New and Old Testament." 39

Cusanus juga menegaskan bahwa Al-Qur'an pasti membawa berkah bagi orang yang membacanya, karena isi Qur'an adalah pengagungan terhadap Allah, meskipun kesalahan terbesarnya adalah menolak Yesus sebagai Tuhan. Cusanus mengatakan,

The goal and intent of the book of the Koran is not only not to detract from God the Creator or from Christ or from God's prophets and envoys or from the divine books of the Testament, the Psalter, and the Gospel, but also to give glory to God the Creator, to praise and to bear witness to Christ (the son of the Virgin Mary) above all the prophets, and to confirm and to approve of the Testament and the Gospel. If so,] then when one reads the Koran with this understanding, assuredly some fruit can be elicited [from it]. ${ }^{40}$

Sebagaimana yang disimpulkan Euler, Cribratio Alkorani menampilkan dua sikap yang tampaknya beroposisi satu sama lain: sikap penolakan (eksklusif) sekaligus sikap penerimaan (inklusif) terhadap Islam. Di satu sisi Cusanus menolak ajaran Islam yang tidak sejalan dengan kekristenan, tapi di satu sisi menampilkan keharmonisan ajaran Qur'an dengan Injil.

Melihat tulisan Cusanus ini, kita dapat menyimpulkan dua hal. Pertama, Cusanus berani menyatakan kebenaran Injil dan mengkritik ajaran Islam yang bertentangan dengan kekristenan. Namun, kritik yang disampaikan Cusanus ini tidak berdiri sendiri, melainkan bersama dengan sikap bersahabat, yaitu keterbukaan Cusanus untuk mencari dasar bersama antara

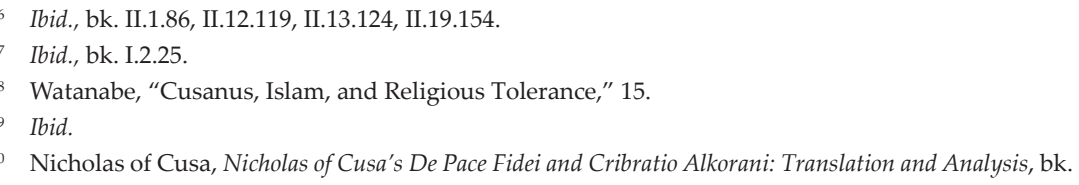


Kristen dan Islam. Meski tujuan ditulisnya Cribratio Alkorani adalah untuk mengkritik Islam sesuai dengan kemauan Paus Pius II, Cusanus mampu menunjukkan masih ada hal positif dalam Islam. Kekhasan Cusanus yang selalu ingin mendamaikan kubu yang berbeda tetap dapat ditemukan dalam Cribratio Alkorani, meski ia menulis buku itu di bawah tekanan Paus Pius II yang membenci Islam dan pengaruh gurunya, Ramon Lull. Oleh sebab itu, ada sisi subversif yang tersirat dalam Cribratio Alkorani, di mana Cusanus sebenarnya menolak posisi Paus Pius II yang memusuhi Islam. Sebagaimana istilah Watanabe, teologi Cusanus adalah Theologia Sermocinalis, yaitu teologi yang selalu ingin melanjutkan dialog. ${ }^{41}$

Kedua, Cusanus mendekati konflik dengan cara nirkekerasan. Sebagian orang berpendapat bahwa cara ini tidak mungkin berhasil di masa kini. Namun, Cusanus telah setidaknya mencoba walaupun sebelum menampilkan sikap akhirnya, dia telah meninggal di Todi. Namun di antara mayoritas orang yang mendukung pedang dan darah, Cusanus masih memegang prinsip perdamaian. Seperti yang dikatakan Biechler, "And, even though their ideal never materialized, it cannot be said to have failed, as did the papal crusade program, dismally. For their ironic ideal remains alive, but as a Christian option the crusade is dead." 42

Model Pendekatan Toleransi Nicholas Cusanus: Eksklusif, Inklusif atau Pluralis?

Dari penjabaran kedua karya Cusanus di atas, muncul sebuah pertanyaan: Model pendekatan apakah yang digunakan Cusanus mengenai toleransi terhadap agama-agama lain? Model yang paling umum digunakan dalam teologi agama-agama adalah model tripolar yang dikemukakan pertama-tama oleh Alan Race (1983), yaitu: model eksklusif, inklusif, atau pluralis. ${ }^{43}$ Ketiga model ini menjabarkan bagaimana agama Kristen melihat agama lain khususnya mengenai keselamatan. Model eksklusif meyakini bahwa tidak ada keselamatan di luar gereja (extra ecclessia nulla salus). Model inklusif mengatakan bahwa keselamatan tetap ada dalam Kristus saja, namun Kristus memiliki banyak jalan menuju diri-Nya. Sedangkan model pluralis meyakini bahwa keselamatan dapat diperoleh dari agama atau kepercayaan manapun, sebab Tuhan tidak dapat dibatasi oleh satu agama tertentu.

\footnotetext{
${ }^{41}$ Watanabe, "Cusanus, Islam, and Religious Tolerance," 18.

42 Biechler, "Interreligious Dialogue," 14.

43 Alan Race, Christians and Religious Pluralism: Patterns in the Christian Theology of Religions (London: SCM Press, 1983)., 1-70.
} 
Dari ketiga model tripolar, model manakah yang paling dekat dengan pemikiran Cusanus? Hal ini menjadi perdebatan di antara ahli-ahli yang meneliti Cusanus. Menurut John Hick, pendekatan yang digunakan Cusanus adalah pendekatan pluralisme, yang menganggap bahwa semua agama sama dan sejajar. Menurut Hick, kata "satu" dalam pernyataan Cusanus "satu agama, beragam ritual," adalah semua agama yang sebenarnya adalah sebuah kesatuan. ${ }^{44}$ Namun demikian, menurut Aikin dan Aleksander, Cusanus juga menekankan bahwa untuk memahami bahwa semua agama adalah sejajar, dibutuhkan pemahaman teologi yang benar mengenai Allah Trinitas dalam agama Kristen. ${ }^{45}$ Dalam hal ini ada unsur eksklusivisme dalam pandangan Cusanus: untuk memperoleh pemahaman pluralisme yang benar, seseorang tetap harus memahami teologi Kristen, meski Cusanus tidak pernah menekankan pentingnya seseorang menganut agama Kristen untuk memiliki pemahaman ini.

Unsur eksklusivisme dalam pandangan Cusanus ini juga diakui oleh beberapa peneliti Cusanus. Sejalan dengan Aikin dan Aleksander yang meyakini bahwa Cusanus menaruh agama Kristen di atas agama-agama lain. ${ }^{46}$ Campi mengatakan,

This is not to say that each religion is of equal value or worth; he believed that the founders of world religions were inspired by God, but the human equation got in the way, and led to various imperfections which need to be purified in order for the members of those religions to see how their faith and tradition ultimately point to what is found in the Christian faith. ${ }^{47}$

Demikian pula, bertentangan dengan pandangan Hick, Rita GeorgeTvrtkovic berpendapat bahwa toleransi Cusanus pada keberagaman ritual tidak menjadikan Cusanus seorang pluralis murni. Menurut Tvrtkovic, Cusanus memisahkan antara ritual dengan agama,

Nicholas' acceptance of ritual diversity makes sense, given that in the years directly preceding the fall of Constantinople in 1453, he had been actively engaged in efforts to reconcile the Eastern and Western churches. But in De Pace Fidei, Nicholas tries to separate 'rite (ritus)' from 'religion (religio)' or 'faith' (fides). ${ }^{48}$

Namun demikian, tidak berarti bahwa Cusanus adalah seorang eksklusivis murni. Cusanus sendiri menekankan bahwa semua agama

${ }^{44}$ John Hick, Christian Theology of Religions: The Rainbow of Faiths (Louisville, KY: Westminster John Knox Press, 1995), 36-37.

45 Scott F. Aikin and Jason Aleksander, "Nicholas of Cusa's De Pace Fidei and the Meta-Exclusivism of Religious Pluralism," International Journal for Philosophy of Religion 74, no. 2 (2013): 227.

46 Ibid., 2.

47 Campi, “Early Reformed Attitudes towards Islam," 135.

48 Rita, 661. 
pada dasarnya adalah satu. Pandangan Cusanus kemungkinan berada di antara pluralisme dan eksklusivisme. Roger A. Johnson menempatkan posisi Cusanus dalam inklusivisme lunak (soft inclusivism). ${ }^{49}$ Inklusivisme lunak ini berada di antara pandangan inklusivisme murni dan pluralisme. Pemikiran ini pertama-tama digagas oleh Jaques Dupuis, ${ }^{50}$ namun istilah "inklusivisme lunak" dimunculkan oleh Johnson sendiri. Menurut Johnson, Cusanus memahami semua agama sebagai ekspresi dari Allah Trinitas, dan ini bersifat universal, namun demikian Cusanus meyakini bahwa kekristenan mengekspresikan hal ini dengan lebih baik dibandingkan agama-agama lainnya walaupun Cusanus sendiri menolak bahwa kekristenan adalah agama yang sempurna memahami Allah. ${ }^{51}$

Jos Decorte menggunakan istilah yang berbeda dengan Johnson untuk mendefinisikan pendekatan Cusanus. Decorte menyebut pendekatan Cusanus sebagai pendekatan konjektura (conjectura). Jika diterjemahkan, posisi konjektura ada di tengah-tengah, yaitu di antara posisi "menduga-duga akan kebenaran" dan posisi "yakin bahwa yang dipercayai adalah kebenaran absolut." $52 \mathrm{Hal}$ ini, menurut Decorte, sejajar dengan posisi filosofis Cusanus dalam karya-karya lainnya, mengenai coincidentia oppositorum, aktualitas dan potensialitas, konsep maksimum dan minimum..$^{53}$ Cusanus meyakini bahwa tidak ada seorang pun yang dapat memiliki kebenaran yang absolut. Kebenaran absolut adalah milik Allah yang adalah misteri, tidak seorang pun mampu memahaminya, "Nonetheless, Absolute Wisdom, as it is [in itself], is never attainable in something other [than itself]. ${ }^{454}$ Masingmasing orang atau agama hanya dapat mendekati kebenaran tersebut. Pendekatan-pendekatan tersebut dibutuhkan untuk semakin mendekati kebenaran absolut. Decorte mengatakan, "The more redundant the (particular) truth appears to be, the more weneed it. After all, this particular (historical, cultural, contingent) truthis our only way of bringing up the Absolute." ${ }^{55}$ Dalam hal ini dapat disimpulkan bahwa baik Johnson maupun Decorte memiliki pandangan yang mirip mengenai pendekatan Cusanus, meski keduanya menggunakan istilah yang berbeda.

49 Roger A. Johnson, Peacemaking and Religious Violence: From Thomas Aquinas to Thomas Jefferson (Cambridge: The Lutterworth Press, 2009), 155.

50 Jaques Dupuis, Toward a Christian Theology of Religious Pluralism (New York: Orbis Books, 1997), 53.

51 Johnson, Peacemaking and Religious Violence : From Thomas Aquinas to Thomas Jefferson, 156.

52 Jos Decorte, "Tolerance and Trinity," in Conflict and Reconciliation: Perspectives on Nicholas of Cusa, ed. Inigo Bocken (Leiden: Brill, 2004), 113.

53 Lih. Karya Cusanus yang lain seperti: De Possest, De Docta Ignorantia.

54 Nicholas of Cusa, Nicholas of Cusa's De Pace Fidei and Cribratio Alkorani: Translation and Analysis, chap. 4.12 .

55 Decorte, “Tolerance and Trinity,” 115. 
Meskipun posisi Cusanus yang berada di tengah-tengah ini patut diberikan apresiasi khususnya di abad pertengahan, Biechler mengkritik bahwa posisi Cusanus ini justru telah melakukan reduksi terhadap doktrin-doktrin Kristen itu sendiri. Contohnya, Cusanus hanya berfokus pada doktrin-doktrin Kristen seperti trinitas, inkarnasi, dan penebusan, tetapi sama sekali tidak membahas mengenai gereja, otoritas, sakramen, dan lainlain. Bahkan Cusanus sendiri menegaskan bahwa tidak ada seorang pun dapat memahami Allah, termasuk orang Kristen sendiri, "Assuredly, then, since it surpasses all the senses and every intellect and every name and everything nameable, it is not said to be one or three or good or wise or Father or Son or Holy Spirit." ${ }^{66}$ Menurut Biechler, reduksi doktrinal yang dilakukan Cusanus didasarkan pada "an impatience which seems to see dogmatic differences as obstructing human desires for peace and intimacy." ${ }^{57}$ Kerinduannya akan sebuah perdamaian membuat Cusanus mengurangi perbedaan dan berfokus pada kesamaan, yang menimbulkan risiko untuk disalahpahami, baik dari dalam lingkungan Kristen sendiri, maupun dari luar.

Meskipun pandangan Cusanus memiliki kelebihan dan kekurangan, namun sebagaimana yang disimpulkan Decorte, ini adalah pandangan yang mencoba menjembatani agama-agama tanpa meninggalkan ortodoksi kristiani yang paling inti: Trinitas. Konsep Trinitas adalah konsep universal yang tidak mungkin ditolak oleh semua agama, khususnya Trinitas sebagai prinsip unitas (kesatuan), aequalitas (kesejajaran), dan connexio (relasi). Pendekatan pada agama-agama lain dapat dilakukan melalui prinsip-prinsip Trinitas tersebut. Decorte mengatakan,

To modern ears, this may sound much too pretentious. After all, how can a roman catholic claim to understand the Koran better than Muslims themselves, unless on the basis of an Absolute (catholic) Truth that is (sub)consciously at the heart of his judgement? Perhaps Nicolas' project is a little too optimistic and too dynamic... It is certain, however, that he was looking for that bridge from a profoundly Christian inspiration which had bid farewell to all absolute claims to truth. Central to this inspiration is the trinitary conjecture, which Nicolas refuses to let go of. ${ }^{58}$

\section{Refleksi dan Aplikasi Pemikiran Cusanus terhadap Konflik Antaragama di Indonesia}

Pendekatan yang digunakan Cusanus untuk melihat agama-agama lain dapat menjadi sumbangsih bagi keragaman agama di Indonesia. Dalam

56 Norman Housley, "Aeneas Silvius Piccolomini, Nicholas of Cusa, and the Crusade: Conciliar, Imperial, and Papal Authority," Church History 86, no. 3 (2017): II.1.88.

57 James E Biechler, "Christian Humanism Confronts Islam: Sifting the Qur'an with Nicholas of Cusa," Journal of Ecumenical Studies (1975): 13.

58 Decorte, "Tolerance and Trinity," 117. 
bagian ini, akan dipaparkan empat refleksi dan aplikasi pemikiran Cusanus terhadap konflik antaragama di Indonesia.

Pertama, pendekatan Cusanus adalah antikekerasan yang dapat membantu masyarakat Indonesia untuk tidak mengakhiri konflik antaragama pada kekerasan fisik. Seperti yang telah diungkapkan sebelumnya, kekhawatiran akan kehadiran dan dominasi agama lain dalam suatu daerah yang beragama tertentu telah menjadi dasar dari konflik antaragama. Dalam konteks Eropa di masa Cusanus, umat Katolik/Kristen di Eropa khawatir dengan kekuatan militer Ottoman Turki, agama Islam juga akan mendominasi Eropa. Di Indonesia sendiri, contohnya di konflik Poso, jelas terlihat bahwa keputusan tokoh Rusli Laboio untuk pindah ke agama Kristen dan juga tingkah laku pemuda Kristen yang melempari masjid di Tegalrejo membuat umat Islam, yang tadinya minoritas, merasa terancam..$^{59} \mathrm{Hal}$ ini berakhir pada kerusuhan dan kekerasan fisik.

Dalam hal ini pemikiran Cusanus memberikan refleksi khususnya bagi umat Kristen untuk menyikapi konflik antaragama yang ada di Indonesia. Cusanus tidak menggunakan cara kekerasan untuk memenangkan konflik, meski orang-orang Kristen di zamannya mengambil langkah kekerasan. Sebaliknya Cusanus mengambil langkah dialogis dengan cara mencari landasan bersama (common ground) bagi agama-agama, yang dalam hal ini adalah pemahaman akan Trinitas.

Kedua, pendekatan Cusanus dapat menjadi sebuah refleksi bahwa konflik agama seringkali digunakan dalam kepentingan politik. Dalam konteks Cusanus, terlihat bahwa Paus Pius II mengatasi keadaan yang memanas dengan menyuruh Cusanus menulis buku yang mengkritik agama Islam. Namun, dibandingkan mengikuti keinginan Paus Pius II sepenuhnya untuk menulis buku yang memusuhi Islam, Cusanus menulis buku tersebut dengan paham subversif, bahwa Islam juga memiliki kebenaran dalam dirinya dan bahkan memiliki kesejajaran dengan Injil.

Situasi yang terjadi pada masa hidup Cusanus sedikit banyak memiliki kemiripan dengan konteks di Indonesia. Meskipun tidak merujuk pada perebutan kekuasaan atau perang, tidak disangkali bahwa acapkali konflik antaragama di Indonesia digunakan pula dalam kepentingan politik. Sebagai contoh, kasus konflik GKI Yasmin, pada tahun 2008 izinnya dibekukan karena ada keberatan dari forum ulama dan ormas Islam se-Kota Bogor. Pemerintah Kota Bogor ikut andil dalam menutup gedung gereja tersebut, sehingga sejak tahun 2010, jemaat GKI Yasmin beribadah di trotoar. Kasus ini menurut Firdaus M. Yunus, telah menjadi sebuah kasus

\footnotetext{
59 Firdaus M Yunus, "Konflik Agama Di Indonesia Problem Dan Solusi Pemecahannya," Substantia 16, no. 2 (2014): 222.
} 
yang ditunggangi politik,

Kasus ini pada awalnya menyangkut perizinan saja yang digugat oleh sebagian umat Islam. Namun belakangan persoalan ini semakin meluas karena sudah ada yang mem-blow up-nya, sehingga kasus ini tidak lagi murni kasus agama tetapi sudah mengarah ke kasus politik. ${ }^{60}$

Atau sebut saja kasus penistaan agama yang dituduhkan ke Basuki Tjahaja Purnama tahun 2017, yang mendatangkan mobilisasi massa besar-besaran lewat aksi 411 dan 212. Menurut Budi Kurniawan, kasus ini "melebar menjadi ladang politik praktis untuk menyampaikan ajakan yang mereka pahami tentang haramnya kepemimpinan nonmuslim dalam Islam. “61

Dalam hal ini, umat beragama di Indonesia, khususnya umat Kristen, diajarkan untuk peka bahwa konflik agama di Indonesia rawan ditunggangi politik. Dalam menghadapi hal ini, sikap Cusanus dapat diteladani. Di satu sisi, dia mengikuti kehendak Paus sebagai kuasa tertinggi pada saat itu, namun di sisi lain dia juga tidak segan memberikan pandangan yang bertentangan dengan Paus. Sebagaimana Rasul Paulus memerintahkan bagi umat untuk tunduk pada pemerintah dalam surat Roma, ${ }^{62}$ umat Kristen juga harus tunduk pada pemerintah. Namun sebagaimana Yesus juga menekankan perlawanan terhadap ketidakadilan, umat juga harus berani menampilkan sikap subversif.

Ketiga, pemikiran Cusanus dapat diaplikasikan bagi pendekatan terhadap keragaman agama di Indonesia melalui jalan dialog. Menurut pengamatan penulis, umat Kristen di Indonesia masih belum memahami pentingnya dialog antaragama yang bersifat inklusif-trinitaris. Sementara dialog antaragama yang terbuka dianggap terlalu liberal dan tidak alkitabiah. Menurut Harmakaputra, pandangan-pandangan negatif terhadap tradisi religius nonkristen lahir melalui tradisi Barat khususnya pada era kolonial. ${ }^{63}$ Warisan kolonial itu terus dikembangkan di zaman pascakolonial di Indonesia, sehingga orang Kristen zaman sekarang pun tetap masih memiliki stereotip negatif terhadap nonkristen, bahkan tidak jarang menghindari pembicaraan mengenai tradisi agama lain jika tujuannya bukan untuk mengkritik.

$60 \quad$ Ibid., 225.

61 Budi Kurniawan, "Politisasi Agama Di Tahun Politik: Politik Pasca-Kebenaran Di Indonesia Dan Ancaman Bagi Demokrasi," Jurnal Sosiologi Agama 12, no. 1 (2018): 134.

62 Roma 13:1-2 (TB), “Tiap-tiap orang harus takluk pada pemerintah yang di atasnya, sebab tidak ada pemerintah, yang tidak berasal dari Allah; dan pemerintah-pemerintah yang ada, ditetapkan oleh Allah. Sebab itu barangsiapa melawan pemerintah, ia melawan ketetapan Allah dan siapa saja yang melakukannya, akan mendatangkan hukuman atas dirinya.

63 Hans Abdiel Harmakaputra, Melepas Bingkai (Jakarta: Grafika Kreasindo, 2014), 126. 
Pandangan Cusanus memberikan contoh kepada kita. Meskipun Cusanus adalah seorang yang lahir dalam tradisi Barat, namun ia mampu mengakui adanya kebenaran dalam agama-agama lain. Tentu ada partikularitas Kristen dan agama lain yang bertentangan satu sama lain. Kita dapat memberikan kritik pada bagian tertentu dari partikularitas agama lain, sebagaimana yang dilakukan Cusanus, tanpa menghakimi bahwa keseluruhan agama tersebut adalah salah. Dengan mengembangkan sikap menghargai namun juga kritis, umat Kristen seharusnya mampu dijadikan teladan oleh penganut agama lain, yang juga memiliki partikularitasnya masing-masing.

Masih menurut pengamatan penulis, dialog antaragama di Indonesia sudah banyak dilakukan. Bahkan sejak era Orde Baru pun, dialog antaragama sudah dilaksanakan sebagai agenda politik. Di era reformasi dan khususnya era digital saat ini, dialog antaragama semakin menjamur. Berbagai dialog ini dapat dilakukan dan disebarkan lewat media-media sosial dan internet. Namun tidak jarang dialog-dialog antaragama hanya berakhir pada perdebatan, saling mengkritik dengan pedas, dan malah berujung konflik. Hal ini disebabkan karena sebenarnya masing-masing perwakilan agama lain tidak memahami secara utuh konsep agama lain yang dikritiknya.

Melihat dari apa yang dialami Cusanus di zaman itu, dialog antaragama sangat sulit dilakukan karena adanya situasi konflik yang memanas antara Islam dan Kristen. Segovia dan Cusanus mencetuskan sebuah dialog antaragama, di mana keduanya mempelajari agama Islam dengan tekun. Oleh sebab itu jika dialog hendak dilakukan, harus dipastikan bahwa komparasi berjalan selaras dengan pemahaman akan agama yang akan dibandingkan. Indonesia harus memiliki teolog-teolog yang mendalami agama-agama dan teologi komparatif. Harmakaputra menekankan pentingnya peran lembaga-lembaga perguruan tinggi teologi Indonesia untuk berperan di dalam diskursus teologi agama-agama Indonesia. ${ }^{64}$

Selain itu, sebagaimana Segovia dan Cusanus merupakan pencetus diadakannya dialog antaragama, gereja-gereja di Indonesia juga dapat menjadi pencetus bagi diadakannya dialog antaragama di Indonesia, dengan cara memberikan waktu dan tempat, dan juga melatih jemaat berpikiran terbuka terhadap agama-agama lain. Meskipun pemerintah sejak tahun 2017 menekankan pentingnya pendidikan mengenai Pancasila, termasuk toleransi, diperkuat pada jajaran perguruan tinggi di Indonesia, tidak menutup kemungkinan gereja pun dapat mendukung visi dan misi pemerintah 
memperkuat toleransi khususnya dalam ranah beragama. ${ }^{65}$

Terakhir, umat Kristen di Indonesia dapat belajar bertoleransi dengan lebih mendalam saat mempelajari pemikiran Cusanus ini. Decorte berargumen bahwa konsep toleransi yang ditekankan Cusanus baik dalam hidup maupun karyanya bukanlah "toleransi basa-basi." Toleransi basabasi yang dimaksud di sini adalah sikap acuh tak acuh, selama agama lain tidak mengganggu kita, maka biarkan saja mereka meyakini apa yang mereka inginkan. Hal ini, menurut Decorte, adalah toleransi yang dingin dan masa bodoh. Konsep toleransi yang ditunjukkan Cusanus, sebaliknya, memiliki makna yang substansial. Pertama, toleransi bermakna tolerare (menanggung/menahan), artinya kita bersedia menahan beban yang muncul dari perbedaan kita dengan orang lain. Kedua, toleransi bermakna tollere (mengangkat/membawa), artinya kita mau untuk mengangkat beban yang ditanggung orang lain karena mereka berbeda dengan kita, lalu menaruhnya di suatu tempat. Kedua makna ini bermaksud bahwa toleransi seharusnya berusaha menghilangkan tembok pemisah (yang adalah perbedaan) antara kedua pihak. Toleransi semacam inilah yang dibutuhkan di Indonesia dalam konteks keberagaman agama yang ada. Setiap dialog antaragama, dengan demikian, harus dilaksanakan atas dasar toleransi tersebut. Bukan berarti kita tidak boleh memberikan kritik pada agama lain, kritik dapat kita sampaikan dalam suasana persahabatan (Amica Censura). Seperti yang dikatakan Decorte, "That is the tolerance of humanity, of the confrontation in dialogue and in reply, which Nicholas (and Juan de Segovia) calls contraference." 66

\section{Daftar Pustaka}

Aikin, Scott F., dan Jason Aleksander. "Nicholas of Cusa's De Pace Fidei and the Meta-Exclusivism of Religious Pluralism." International Journal for Philosophy of Religion 74, No. 2 (2013): 219-235.

Biechler, James E. “Christian Humanism Confronts Islam: Sifting the Qur'an with Nicholas of Cusa." Journal of Ecumenical Studies (1975): 1-14.

Biechler, James E. "Interreligious Dialogue." Dalam Introducing Nicholas of Cusa: A Guide to a Renaissance Man. Di edit oleh Christopher M. Bellitto, Thomas M. Izbicki, dan Gerald Christianson, 270-296. New York: Paulist Press, 2004.

Biechler, James E. "Nicholas of Cusanus and Muhammad: A FifteenthCentury Encounter." The Downside Review 101, no. 342 (1983): 3.

65 Ristekdikti, "Surat Edaran Menristekdikti: Penguatan Pendidikan Pancasila Dan MKWU Pada Pendidikan Tinggi," accessed July 14, 2020, https://lldikti12.ristekdikti.go.id/2017/08/30/surat-edaranmenristekdikti-penguatan-pendidikan-pancasila-dan-mkwu-pada-pendidikan-tinggi.html.

66 Decorte, "Tolerance and Trinity," 115-116. 
Campi, Emidio. "Early Reformed Attitudes towards Islam." Theological Review of the Near East School of Theology 31, no. 1985 (2010): 131-151.

CNN Indonesia. "Sewindu, Umat GKI Yasmin-HKBP Filadelfia Natal Di Luar Istana." 25 Desember 2019. Diakses pada Mei 15, 2020. https://www.cnnindonesia.com/nasional/20191225185015-20-459879/ sewindu-umat-gki-yasmin-hkbp-filadelfia-natal-di-luar-istana.

Collins, Gerald O', dan Edward G Farrugia. Kamus Teologi. Yogyakarta: Kanisius, 1996.

Dallmayr, Fred. "Desire and the Desirable: Nicholas de Cusa's Interfaith Imagination." Religion and the Arts 12, no. 1-3 (2008): 420-433.

Decorte, Jos. "Tolerance and Trinity." Dalam Conflict and Reconciliation:

Perspectives on Nicholas of Cusa. Diedit oleh Inigo Bocken, 107-118.

Leiden: Brill, 2004.

Dupuis, Jaques. Toward a Christian Theology of Religious Pluralism. New York: Orbis Books, 1997.

Euler, Walter Andreas. "A Critical Survey of Cusanus's Writings on Islam." Dalam Nicholas of Cusa and Islam: Polemic and Dialogue in the Late Middle Ages. Di edit oleh Ian Christopher Levy, Rita George-Tvrtković, dan Donald Duclow, 20-29. Leiden: Brill, 2014.

Harmakaputra, Hans Abdiel. Melepas Bingkai. Jakarta: Grafika Kreasindo, 2014.

Hick, John. Christian Theology of Religions: The Rainbow of Faiths. Louisville, KY: Westminster John Knox Press, 1995.

Housley, Norman. "Aeneas Silvius Piccolomini, Nicholas of Cusa, and the Crusade: Conciliar, Imperial, and Papal Authority." Church History 86, no. 3 (2017): 643-667.

Johnson, Roger A. Peacemaking and Religious Violence: From Thomas Aquinas to Thomas Jefferson. Cambridge: The Lutterworth Press, 2009.

Kurniawan, Budi. "Politisasi Agama Di Tahun Politik: Politik PascaKebenaran Di Indonesia Dan Ancaman Bagi Demokrasi." Jurnal Sosiologi Agama 12, no. 1 (2018): 133-154.

Mahadi, Samala. "Lima Konflik Agama Terbesar Di Indonesia." Berita Properti 99. 24 Desember 2019. Diakses pada 15 Mei 2020. https:// www.99.co/blog/indonesia/konflik-agama-indonesia/

Meuthen, Erich. Nicholas of Cusa: A Sketch for a Biography. Washington D.C.: The Catholic University of America Press, 2010.

Nicholas of Cusa. Nicholas of Cusa's De Pace Fidei and Cribratio Alkorani: Translation and Analysis. Di edit oleh Jasper Hopkins. Minneapolis: The Arthur J. Banning Press, 1994.

Purwanti, Puput. "Tujuh Contoh Konflik Antar Agama Yang Pernah Terjadi 
Di Indonesia." Hukamnas. 28 Desember 2017. Diakses pada 15 Mei 2020. https://hukamnas.com/contoh-konflik-antar-agama.

Race, Alan. Christians and Religious Pluralism: Patterns in the Christian Theology of Religions. London: SCM Press, 1983.

Ristekdikti. "Surat Edaran Menristekdikti: Penguatan Pendidikan Pancasila dan MKWU Pada Pendidikan Tinggi." Diakses pada 14 Juli 2020. https:// lldikti12.ristekdikti.go.id/2017/08/30/surat-edaran-menristekdikti-penguatan-pendidikan-pancasila-dan-mkwu-pada-pendidikan-tinggi. html.

"Rizieq Shihab Dilaporkan Ke Polisi, Dituduh Lecehkan Umat Kristen." BBC Newws. 26 Desember 2016. Diakses pada 14 April 2020. https://www. bbc.com/indonesia/indonesia-38435195.

“Penistaan Agama." Tempo. Diakses pada 15 Mei 2020. https://www.tempo. co/tag/penistaan-agama.

Volf, Miroslav. Allah: A Christian Response. New York: Harper Collins, 2011. Watanabe, Morimichi. "Cusanus, Islam, and Religious Tolerance." Dalam Nicholas of Cusa and Islam: Polemic and Dialogue in the Late Middle Ages. Di edit oleh Christopher M. Bellitto, Thomas M. Izbicki, and Gerald Christianson, 9-19. New York: Paulist, 2004.

Weiler, Anton G. "Nicholas of Cusa on Harmony, Concordance, Consensus and Acceptance as Categories of Reform in the Church, in De Concordantia Catholica." Dalam Conflict and Reconciliation: Perspectives on Nicholas of Cusa. Di edit oleh Inigo Bocken, 77-90. Leiden: Brill, 2004. http://repositorio.unan.edu.ni/2986/1/5624.pdf.

Yunus, Firdaus M. “Konflik Agama Di Indonesia Problem Dan Solusi Pemecahannya." Substantia 16, no. 2 (2014): 217-228. 